\title{
SELF-PRESENTATION IN A SPEECH OF NEWT GINGRICH ${ }^{1}$
}

\author{
Pamela S. Morgan
}

\section{Introduction}

This paper presents an analysis of a major speech delivered by Newt Gingrich, current Speaker of the United States House of Representatives and an important figure in domestic American politics of the 1980s and especially 1990s. It was his first 'Speaker's inaugural' address, delivered in the House on January 4, 1995, when he was sworn in for his first term as Speaker. The focus is on issues of cognitive linguistics, pragmatics, and discourse analysis, including especially what I am calling Gingrich's 'frames' of self-presentation based in 'traditional' American culture - as well as the use of metonymy and the metaphor 'more is better'. Not included are the equally rich areas of language and gender and other aspects of gender studies, although these issues can be raised at many points.

All politicians manipulate language to achieve their ends, regardless of their political ideologies. The 'inaugural' speech made by a newly elected Speaker of the House presents the representative to his (not yet 'her') colleagues in his new role as their leader and in recent years may set the tone for his - and his party's - political agenda. (For a discussion of the related genre of presidential inaugural addresses, see, e.g., Campbell and Jamieson 1990.) In Gingrich's case, it was even more noteworthy and widely reported because Gingrich was seen by himself and others as the leader of the "Republican revolution," as the Republican party and the media named the Republican majority in the 1994 Congressional elections.

Throughout the speech, Gingrich makes reference to at least seven 'frames' of selfpresentation; see Table 1:

\footnotetext{
${ }^{1}$ A slightly different version of this paper appears as a chapter in my dissertation (directed by George Lakoff and Eve Sweetser, with Robin Lakoff and David Collier). Early versions of this paper were presented at the Conference on Political Linguistics, Antwerp, December 7-9, 1995 (Belgian Linguistic Association) and at the UC Berkeley Department of Linguistics Departmental Colloquium in February 1996; my thanks for the helpful comments received at both presentations, from the members of Robin Lakoff's spring 1995 seminar on political language, from Colleen Cotter, Cornelia Ilie, and Hugo Olaiz, and from an anonymous reviewer for Pragmatics.
} 


\begin{tabular}{l}
\hline Frame 1: The Professor \\
Frame 2: Just Plain Folks \\
Frame 3: The Spokesman for Traditional American Values \\
Frame 4: The (Authoritarian) Leader \\
Frame 5: The Fighter \\
Frame 6: The Cooperator \\
Frame 7: The Visionary
\end{tabular}

TABLE 1

Gingrich's Frames of Self-Presentation

My use of the term 'frame' is based partly on the work of sociologist Erving Goffman and others:

Given their understanding of what it is that is going on, individuals fit their actions to this understanding and ordinarily find that the ongoing world supports this fitting. These organizational premises - sustained both in the mind and in activity - I call the frame of the activity (Goffman 1974:247)

and partly on the concept of an 'idealized cognitive model' (e.g., G. Lakoff 1987).

That is, each of these 'frames' of self-presentation is a multi-element cognitive model with rich traditional linguistic and cultural components and associations, including presuppositions and entailments or inferences, through which a society views, understands, structures, and conducts itself and its activities. Because of this complexity, these cultural frames are often cognitively linked to each other by the intersection or overlap of some of the elements of their idealized cognitive models. For example, the Traditional American Values are generally those held by Just Plain Folks.

Self-presentation frames are culturally pre-formed pieces used to construct 'face', in the sense of the self-image that speakers try to project to their hearers. The selfpresentation frames used by politicians are necessarily widely shared in the general culture, in order to serve the social role and political functions of appealing to present and potential supporters, both as a 'good' prototypical American Politician and as a 'good' individual example. (Self-presentation frames may of course also be psychologically based, but I am not examining that function.) Gingrich's political agenda is both explicitly presented and contained in or usefully supported by several of his self-presentation frames.

\section{Self-presentation: The frames}

There is no internal thematic or structural significance to the order of the frames as discussed. Because of space limitations, only a few examples of each frame are presented, but readers should have no difficulty in finding other examples in the text of the speech. For each frame, relevant linguistic markers are identified, including frame-evoking words and phrases, frame-evoking references and allusions, register markers (especially with respect to lexical choice and syntax), discursive style, regular frame-related violations of Gricean maxims, and so on. In many cases, speaker use and hearer recognition of these markers and their effects is dependent on extra-linguistic cultural knowledge. 


\subsection{Frame 1: The Professor}

In interviews and speeches, Gingrich often calls himself a professor of history or an historian. In the early 1970 s, he taught for a few years in the history department of West Georgia College in Carrollton, Georgia, with an emphasis on futurism, and then transferred to the geography department. More recently, he has taught a course on the American character and future, first at Kennesaw State College in Georgia and then at Reinhardt College, a private business college in Waleska, Georgia, after the Georgia Board of Regents' ruling that "a public office holder could not teach at a public university such as Kennesaw" (Warner and Berley 1995: 208) and after considerable criticism that the course was primarily ideologically political in intent. Questions about funding sources have also been widely raised. The course on "Renewing American Civilization" has been videotaped and broadcast on cable television. The topic of his $\mathrm{Ph}$.D. dissertation in history from Tulane University was educational policy in the Belgian Congo, and he did not publish academic articles or books.

-lexical choice (direct reference, e.g., "intellectual," "vague"; frameevoking words, e.g., multisyllabic and/or latinate words)

-references to classic books or authors and/or to modern analytic studies

-more formal register (syntax, lexical choice)

-classroom lecturing style

-extensive detail of content or citation that may often be interpreted (by non-specialists) as violating the Maxim of Quantity

TABLE 2

Linguistic Mechanisms Evoking Gingrich's Frame 1:

The Professor

Although the use of frame-evoking multisyllabic or latinate words is a frequent feature of Frame 1 talk, which is often intended to impress others or to establish authority as well as to convey information and instruct, Gingrich does not use such words in this speech. It is much more important for the leader of a self-labeled 'populist' political movement to emphasize Frame 2, Just Plain Folks. However, because he is also claiming authority, and because his frequent use in interviews and statements of the self-label of 'professor' indicates that it is important to him, he evokes Frame 1 in ways that are less likely to provoke the immediate criticism that he is 'talking over people's heads'. Invoking the Professor frame carries a certain amount of ambivalence in the American context: professors are respected as experts (at present especially because they are often briefly interviewed on television as ad hoc commentators on news events) and therefore have high prestige, but there is also historically a strong 'anti-intellectual' strand in American popular and political tradition (see, e.g., Hofstadter 1963), and professors are often stereotypically either ridiculed or vilified as removed from reality (in an 'ivory tower'). 
In this speech, Gingrich frequently handles this dilemma by mixing Frames 1 and 2 within a single utterance. For instance, the phrase "You see" in example (1) imparts both a Frame 1 lecturing tone (especially given the intonation as delivered) and a Frame 2 'Just Plain Folks' colloquialism:

(1) This is what de Tocqueville wrote: "Often there is not a distinguished man in the whole number. Its members are almost all obscure individuals whose names bring no associations to mind. They are mostly village lawyers, men in trade, or even persons belonging to the lower classes of society." ... But the word 'vulgar' in de Tocqueville's time had a very particular meaning. It is a meaning the world would do well to study in this room. You see, de Tocqueville was an aristocrat. . . (97-103)

In this example, Gingrich has not remained literally accurate. That is, the word "vulgar" does not itself appear in what he has just quoted from "de Tocqueville" (and not the much more common though less 'correct' 'Tocqueville'), although by the Maxim of Relevance he implies that it does; there would otherwise seem to be no need to connect it to the quotation with a "but" or to introduce an archaic meaning of the word at all. The words that do appear in the quotation - "obscure" and "not ... distinguished" - are close in meaning to "vulgar" via its meaning as 'common' or 'populist', but do not offer the same opportunity for reinforcing the Professor frame by explicating the older meaning of a word that is today almost exclusively used in another, here inappropriate, meaning in American English. example:

More often, Gingrich cites a specific modern author or book, as in the following

Such references are admittedly a common academic feature, but in context there is a further effect, related to Grice's Maxim of Quantity. Here Gingrich is giving the audience of this non-academic speech more information than is strictly necessary at an informational level: it is not usual to cite one's references in a political speech. Since this additional information does not contribute to the hearers' needs, it must be intended to serve the needs of the speaker. It is relevant to the hearers - and it is part of the tradition of this genre - to mention the nineteenth-century Henry Clay as a model Speaker, but it is not informationally necessary for either prototypical relevance or tradition to know that Gingrich was just reading a (very long) biography of Clay, and who the author was. Instead, the passage serves to reinforce the Professor frame in both its 'learned' and its 'authority' aspects.

In examples (1), (2), and (3), the Professor frame is also marked by a classroom lecturing style:

(3) I do not know if you have ever thought about this, but for 208 years, we bring [sic] together the most diverse country in the history of the world. (86-87)

Gingrich also seems to make it easy for hearers to recover or impose a presupposition of ignorance as applied to them, if they choose to do so for political reasons. Hearers who make such an implicature - and not all would - could then see this passage as contributing to their negative perception of the Speaker. His use of "but" is also open to such a difference of opinion. If a hearer so chooses, therefore, s/he can be insulted by what can be 
interpreted as another violation of the Maxim of Quantity: i.e., I do not know if you have ever thought about this, but even if you have I am going to say it anyway because I am lecturing you, presumably because I know more than you. On the other hand, hearers who are not inclined to such a negative interpretation may feel edified by 'Professor' Gingrich's instruction or even flattered by the weaker but perhaps still possible opposite implication that Gingrich thinks that they might have thought about this important topic. In any case, they are immediately made a part of the thought by his use of "we."

By means of this appeal to American history, he is able to connect this frame not only to Frame 4 (The [Authoritarian] Leader) both generally and specifically (professors are conventionally seen as people with authority to speak, especially on issues connected with their specialties) but also strongly to Frame 3 (The Spokesman for Traditional American Values) and by extension Frames 5 (The Fighter), 6 (The Cooperator), 7 (The Visionary), and even 2 (Just Plain Folks), all of which represent specific American values.

\subsection{Frame 2: Just Plain Folks}

Gingrich is certainly not the only politician to exploit the powerful and traditional 'Just Plain Folks' American political frame. It is necessarily closely related to Frame 3 (The Spokesman for Traditional American Values), since the belief in America as a populist democracy is old and deep in American culture and self-image, and it appears often at the beginning of 'Speaker's inaugural' speeches. Gingrich's characterization of the antiaristocratic and diverse nature of the House and of America itself (86-115) is found also in the 'inaugural' speeches of other Speakers (e.g., Foley 1989: 101 Congressional Record 1989: 10802:col. 2).

Although this frame is most directly evoked by words such as "commoners" (114115; cf. 97-106), by far the most common reference to this frame involves register, including colloquialisms - especially but not restricted to the American colloquial impersonal "you" - and other lexical, syntactic, and/or pronunciation markers of informality. For example, in delivering the speech Gingrich often pronounced "let me" as "lemme;" contractions were common; and at one point (316) the written version has "isn't," but as delivered it was even more colloquial, as well as emphatic: "that ain't enough." See Table 3 for the markers of Frame 3 as seen in this speech:

The following examples contain other clear markers of the informal register of Frame 2:

(4) I am sorry, guys, it just did not quite work out. (8)

(5) It is a little strange if you are from a dictatorship to explain you are called the whip but you do not really have a whip (125-126)

(6) So, leave on the first bell, not the second bell. Okay? (163-164; overlap with Frame 4, The [Authoritarian] Leader) 
The simplified, linearized syntax and register of example (5) may also carry either a humorous intention or some sense of Frame 1 (i.e., he is explaining something) which could again be interpreted by the hearers as reflecting either a desire to be helpful or a presupposition of their ignorance.

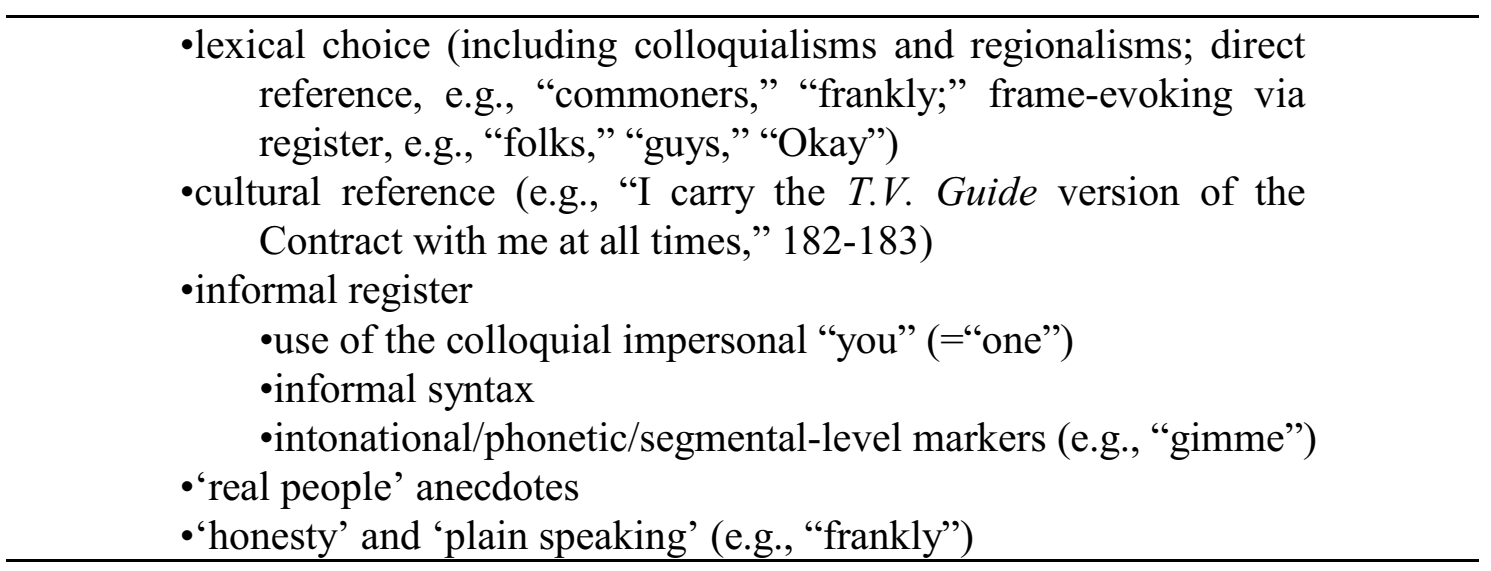

TABLE 3

Linguistic Mechanisms Evoking Gingrich's Frame 2:

Just Plain Folks

The anecdote from which example (5) is taken (119-137) reflects an important feature of American political speeches in general that serves to reinforce this Frame 2 emphasis on the populist nature of America's view of itself, namely, the use of anecdotes tied in some way to 'real people'. President Bill Clinton's State of the Union addresses, for example, have used identifiable individuals for this purpose, naming them, bringing them to the chamber, and having them stand up when they are mentioned. It is common, however, for politicians to tell 'personal' stories with no specific names or faces attached. President Reagan used these anonymous, generic anecdotes very effectively. (For a discussion of the non-factual nature of Reagan's anecdotes, see Johnson 1991: 59-60 and Erickson 1985.) Gingrich's story of the visitors from Russia and Lithuania (119-137) in many ways more closely resembles in style the stories of Reagan than those of Clinton.

The provenance of Gingrich's second, very large gavel (34-38) is also linked to a brief Frame 2 'real person' anecdote - this one with a name attached - as well as implicitly to an iconic 'historical' (but factually untrue) story that is relevant to both Frame 2 and Frame 3: that of George Washington's chopping down of the famous cherry tree and then his honest admission that he had done it, because he could not tell a lie. ${ }^{2}$

The Frame 3 Traditional American Value of 'honesty' is part of the Just Plain Folks frame element of 'plain speaking,' itself another manifestation of the populist antiintellectual (versus vagueness and 'highfalutin' language) and anti-politician (versus 'doubletalk' and deception) stances. Gingrich signals 'plain speaking' by his frequent use

\footnotetext{
${ }^{2}$ This story was apparently invented by Mason Locke Weems, called "Parson Weems;" it first appears in 1806 in the fifth edition of this book The life and memorable actions of George Washington.
} 
of "genuinely" and even more by his extremely frequent use of "frankly," as in examples (8) and (9):

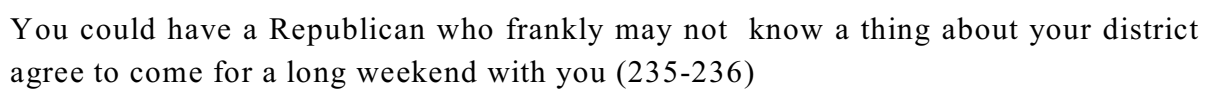

[A]nd we got into what I think frankly has been a pretty distorted and cheap debate over orphanages (273-274)

"Frankly" is often working here at and as 'face value' as part of Gingrich's selfpresentation, suggesting that the hearers should accept the assertion as merely a statement of fact without any speaker bias. That is - according to his self-presentation - Gingrich is objective, and even when the truth is unpleasant, he can face it, although he warns his hearers that something unpleasant is coming; therefore he is also not unfeeling. In example (8), the unpleasantness is not related to the hearer's reception of the utterance, but rather to the situation: Republicans need to go on these visits, but it is not a good thing that they do not already know about your district. Example (8) may also evoke the Professor frame: let me instruct you as to the situation.

"Frankly" may also serve as a plea for or assertion of belief or authority, whether as a disarming apology, a brave determination to speak the truth, an attempt to bolster a weak case (deflection), a swindle ('look how honest I am' - when I'm lying to you), or an aggressive challenge. "Frankly" in example (9), coupled with "I think" and the intonation stresses of the delivery, has the effect of an aggressive challenge: this is my opinion, and it is the truth, whether you like it or not.

\subsection{Frame 3: The Spokesman for Traditional American Values}

It is not necessary to spend much time on this frame, since as a major frame for all American political speeches it consists of several easily recognizable elements. Frame 2 (Just Plain Folks) and Frame 3 - which overlap extensively - are the two most common frames in the speech, as is appropriate for the leader of a political movement that puts a lot of spoken emphasis on a 'return to the people' (by de-emphasizing the influence of the national federal government) and a return to 'family values':

Table 4 presents the markers of Frame 3 seen in this speech:

- lexical items (direct reference or frame-evoking)

-direct or indirect reference to iconic figures and events of American history

TABLE 4

Linguistic Mechanisms Evoking Gingrich's Frame 3: The Spokesman for Traditional American Values 
Although it is certainly not uncommon for any American politician to appeal to 'our children' as 'our future', in line with the current Republican appeal to 'family values' (which we know by our real-world knowledge is related to the anti-Democratic Frame 5, The Fighter) Gingrich makes many references to children (or to the Frame 2 lexical equivalent, "kids").

Gingrich also refers to Traditional American Values such as hard work:

(11) [W]e were hired to do a job (195)

(12) [C]haracter is the key to leadership (147)

Furthermore, the apparently unremarkable sentiment of example (12) is in fact strongly linked to The Fighter of Frame 5, since the Republicans often attack the Democratic President Clinton on 'character' grounds.

Religion and/or morality are also common Traditional American Values, and are often appealed to by American politicians. Gingrich, however, makes very little use of either ("right thing to do," "moral urgency," 251-253; "the Good Samaritan," 298-300) until the end of his speech. There he quotes from the "Battle Hymn of the Republic" (331332; also a reference point for the abolition of slavery and therefore for black Americans), talks about a prayer-and-fasting day supposedly held by the Constitutional Convention (347-358), and ends with the common formulaic closing of many American political speeches: "Good luck and God bless you" (364). (For the historical inauthenticity of the Constitutional Convention story, see Wills 1995: 7.)

A quite common but somewhat less universally accepted American value recalls the historical populist position that opposes politicians to the rest of 'us'. In the following example, "we" are at first not "politicians" (although this position is immediately negated when "we" as 'non-politicians' shifts to "our" as 'Congress's'):

(13) We should not be happy just with the language of politicians and the language of legislation. We should insist that our success for America is felt in the neighborhoods, in the communities, is felt by real people living real lives (325-327)

Presented as a fundamental American value, this tradition (part of Frame 2, Just Plain Folks, as well as Frame 3) helped the Republicans replace 'career politicians' with a large number of first-time office holders in the Congressional elections of 1994 and helped give Gingrich his visible political power as Speaker.

Another obvious element of the Spokesman for Traditional Values frame consists of the invocation of important iconic figures such as President Roosevelt and Speaker Clay, as well as paeans to American history in general:

(14) $[\mathrm{T}]$ he America we are now going to try to lead grew from that tradition and is part of that great heritage (15-16)

This feature is also linked to Gingrich's American history Professor frame (Frame 1). 


\subsection{Frame 4: The (Authoritarian) Leader}

Table 5 presents some of the important linguistic markers of Frame 4:

\begin{tabular}{l}
\hline •lexical choice (e.g., "leaders," "rule"), including also: \\
•pronoun choice \\
•superlatives \\
•mplicature \\
•directive speech acts \\
$\quad$ (apparent violations here, but see discussion) \\
\hline
\end{tabular}

\section{TABLE 5}

Linguistic Mechanisms Evoking Gingrich's Frame 4:

The (Authoritarian) Leader

Clearly, one role of the Speaker of the House is to lead, so it is not surprising that Gingrich explicitly presents himself as a leader of his fellow Representatives:

(15) Our challenge should not be anything that is just legislative. We are supposed to, each one of us, be leaders. I think my challenge has to be to set as our goal . . (317-318)

However, he does not seem to notice the odd implicature introduced by the denigrating "just" and supported by the anti-politician populism of Frame 2 (Just Plain Folks) that enacting legislation that charts the course of the country is somehow not "be[ing] a leader."

Furthermore, Gingrich's view of leadership is authoritarian. From the beginning of the speech, where he describes governance as "rule," 20), he offers in close proximity both the Cooperator (Frame 6) stance that is a strongly traditional element of the 'Speaker's inaugural speech' genre and the Authoritarian Leader position that seems to be his own. Like so much else in the speech, this Authoritarian position can be viewed either positively - as the Traditional American Value of strong leadership - or negatively - as dictatorship. We have already seen how Gingrich simultaneously appeals to and asserts Authority by violating the Maxim of Quantity; he also asserts Authority by subtle lexical choices ("allowed" rather than, say, 'invited' in example [16] below), by imperatives (example [17]), and by the assumption of the right to speak (example [18]):

(16) I allowed him to come up here and sit and be Speaker (130-131)

(17) Remember, this is the very beginning of perestroika and glasnost. (132)

(18) But let me say about everything else (226-227)

The already mentioned example of the Russian and Lithuanian visitors to Congress from

\footnotetext{
${ }^{3} \mathrm{He}$ describes the last forty years of the Democrats' majority as "rule," a word from the frames of kings and dictators, but, as this discussion of Frame 4 shows, his own approach to leadership can also be described as "rule."
} 
which examples (16) and (17) are taken is also connected with Frame 1, giving a history lesson as a context for the anecdote with Gingrich as the expert who reminds his listeners of the facts. Again, this could be interpreted either as a friendly reminder of an important aspect of the context that they know but perhaps have forgotten, or a lecture that the audience needs because he thinks they are ignorant. Furthermore, its somewhat informal style overlaps with Frame 2 (Just Plain Folks).

In lines 164-165, Gingrich begins with explicit Authority (imperatives) and ends with implicit Authority:

This may seem particularly inappropriate to say on the first day

That is, it may be inappropriate - but I have the authority to say it anyway.

Gingrich presents himself as another type of Authority figure in the passage given as example (20):

(20) I will listen to each of you. I will try to work with each of you. I will put in long hours, and I will guarantee that I will listen to you first. I will let you get it all out before I give you my version (341-343)

Note the register differences between the highly colloquial, Frame 2 "get it all out," which also perhaps most commonly suggests a frame in which someone is emotionally distressed, and the more standard though still relatively informal "giv[ing] you my version," which evokes a frame that is much more reasonable and rational (Frame 4, Authoritarian, and Frame 1, Professorial).

Listening and then "giv[ing] my version" may further suggest to some - especially those predisposed to a negative assessment of Gingrich - an Authoritarian disregard of 'your version'. To his partisans, however, it could be read as a form of dialogue, though not a prototypical conversation with ongoing turntaking. In addition, the language in example (20) may suggest therapeutic dialogue, which involves yet another kind of Authority.

Although psychiatric care and psychotherapy are no longer as highly stigmatized in American society as they previously were, ${ }^{4}$ and although in the $1990 \mathrm{~s}$ it is not uncommon to be or have been under the care of a therapist or at least to have read a therapeutic self-help book or listened to a radio call-in psychologist, these are still not entirely positive cognitive models for all Americans, especially for the stereotypical and symbolically significant Just Plain Folks with their Traditional American Value of selfreliance. Nevertheless, here Gingrich is the therapist and not the patient, so he is not risking much of any stigma that remains. Perhaps more importantly, appeals to psychotherapeutic explanations of and remedies for social as well as personal ills have for several decades been generally acceptable and for many even preferred. For these reasons, a mental health care professional is indeed now often framed as a figure of Authority and

${ }^{4}$ In 1972, for example, Thomas Eagleton was forced to leave the campaign as (Democrat) George McGovern's vice-presidential running mate when it was revealed that as a young man he had undergone treatment for depression. 
trust, even compassion. ${ }^{5}$

This frame is also related to Frame 1, since the prototypical Professor by virtue of great knowledge also has authority to speak on a subject.

It might be argued that Gingrich in fact undermines Frame 4 by constructions that weaken his assertions, such as hypotheticals and negatives ("If we could build that attitude ..., we would be an amazingly different place," 303-304; "Our challenge shouldn't be to balance the Budget or to pass the Contract. Our challenge should not be anything that is just legislative," 316-317), and especially by his extensive use of the "I + verb" construction to preface a propositional statement that would have been complete without it:

(21) Beyond the Contract I think there are two giant challenges.

(202, italics added)

\section{I have said that I think Social Security ought to be off limits. (225, italics added)}

These features are especially noticeable when his inaugural speech is compared with that of Martin in 1947, in which the last previous Republican Speaker laid out an agenda that is strongly reminiscent of the current Contract, but presented very firmly and assertively with many examples of "must": "We must keep the torch of freedom and progress alight in America" (80 Congressional Record 1947:35, col. 3); "The Government's control over the private affairs of the citizens must be ended, and the people's control over their Government must be fully restored;" and so on (pp. 35-36). The Republicans "intend to reduce" Government costs and tax rates, balance the budget, and pay off the national debt (37: col.1): "We have given that promise to the American people, and we intend that it shall be fulfilled" (35: col.1).

Gingrich's version of the Republican agenda is less explicitly assertive. In a time of less American self-certainty and a lack of domestic consensus about the proper role of the federal government, this is perhaps understandable. Instead of "must," he uses other, less powerful auxiliaries: "I hope we can have" (204-205), "is going to be" (312), "we are supposed to . . be" (317-318; notice also the informal style of this passage), "I think our challenge has to be" (318), "This ought to be" (319), "We should insist" (326).

Gingrich's extensive use of the first person singular pronouns ("my" and especially "I") is also very noticeable in comparison with the inaugural speeches of the other Speakers, and gives the speech a strong sense of 'ego'-centricity (i.e., a speaker's focus on $\mathrm{him} /$ herself). As already mentioned, Gingrich does not limit his use of "I" to unavoidable context - e.g., "I agree with everything Congressman Gephardt said" (333-334). Rather, he also uses it in utterances where it adds nothing to the propositional structure and therefore where its effect can be to introduce himself 'unnecessarily' into the discourse (as in examples [21] and [22]). Thus, this construction can serve to foreground Gingrich's ideas and participation by another apparent violation of Quantity.

\footnotetext{
${ }^{5}$ As a self-proclaimed political and social 'conservative', however, Gingrich cannot strongly emphasize psychotherapy, since one of the stereotypical fundamental tenets of 'conservatism' is self-reliance (an element of Frames 2 and 3). (For a discussion of the generalized stereotypical cognitive systems of American 'liberals' and 'conservatives', see G. Lakoff 1996.)
} 
Conversely, this construction can also serve as equivocation, to hedge his assertions, especially since intonationally they are almost throwaway. He may also be trying to be The Cooperator of Frame 6, making suggestions instead of giving commands. Either self-assertiveness or humility would be coherent with at least some of the other frames (humility with Frame 2, Just Plain Folks, and assertiveness with Frames 1, The Professor, and 5, The Fighter), and the hearers' interpretations will most likely be made on ideological grounds.

Whatever the reason, Gingrich's frequent use of "I think" and other verbs in explicit agenda passages is also more in line with current rhetorical preferences, which have become increasingly more 'personal' and less 'oratorical'. 6

\subsection{Some further comments on speech acts}

In the agenda section of his speech, Gingrich uses many performatives, mostly implicit or explicit (but restricted) promises. In the "Contract with America" section (170-201), for example, what does Gingrich promise?

(23) We then say that within the first 100 days ... we shall bring to the House floor the following bills ... (184-185)

To 'say that we shall do' something is usually understood as a prediction or a promise. However, the phrase does not actually promise -implicitly or otherwise - that the bills will be passed - as in fact they mostly were not.

In another passage at the end of the speech he says:

(24) [I] pledge to you that, if each of us will reach out prayerfully and try to genuinely understand each other, if we will recognize that in this building we symbolize America, and that we have an obligation to talk with each other, then I think a year from now we can look on the 104th Congress as a truly amazing institution without regard to party, without regard to ideology. (358-362; "amazing" is an adjective perhaps more associated with 'simple country boys in the big city', i.e., Just Plain Folks, Frame 2, than it is with longterm national politicians)

Once more, Gingrich does not explicitly "pledge" that anything substantive will necessarily result, although one of the most likely interpretations is to understand it that way. 'If-then' constructions can often be interpreted as wishes. However, they can also merely be declaratives as to future cause and effect relationships, even those which the speaker has no intention of desiring or bringing to pass. The closest thing to an explicit promise here is his comment "that we have an obligation to talk with each other" (italics added); furthermore, the use of "recognize" presupposes that the speaker believes that such an obligation does in fact exist. Although obligations are not always met and no conditions

\footnotetext{
${ }^{6}$ As mentioned in the introduction, I have not discussed linguistic gender stereotypes in this analysis, but some of Gingrich's adjectives and speech act hedges are often considered typical 'women's language'. This is in line with the 'privatizing' of American public discourse style (see, e.g., Jamieson 1988; R. Lakoff 1990). (For the pragmatic effects of speech act qualification, see R. Lakoff 1980.)
} 
for such talk are given, this passage will in fact probably be interpreted most often as a promise to be nonpartisan, reinforced perhaps by his use of "will" rather than a simple present or the more prescriptively correct but rarely heard subjunctive ('were to') in the "if"-clause. This is a traditional theme for the 'Speaker's inaugural' speech, addressing as it does members from both parties; Gingrich and the other Republicans in Congress have not in fact carried it out.

At the end of the speech, Gingrich breaks his pattern and uses the explicit verb "promise" (340-341) and the "will" constructions seen above in example (20). However, here as before Gingrich continues to exhibit the typical caginess of many politicians - the caginess for which the occupation is often criticized. That is, he does not promise to act on what he is told, or even to discuss it after "you get it all out" and he "give[s]" you "his version."

Furthermore, despite any good will, if all that Democrats and Republicans can do is "try" to understand each other and if the only way they can talk to each other is to decide that they have an "obligation" to do so, then any agreement will surely be grudging and hard to achieve, despite what Americans think they are hearing. ${ }^{7}$

\subsection{Frame 5: The Fighter}

In general American culture, a willingness to 'stand up for one's beliefs' is one of the Traditional Values of Frame 3. However, this readiness establishes a separate, more specific 'combative' frame in experiential domains that are conventionally viewed as competitive, such as politics. See Table 6 for markers of this Fighter frame:

${ }^{7}$ Before leaving the subject of speech acts, there is one early, intriguing passage worth mentioning:

(i) It is the most marvelous act of a complex giant country trying to argue and talk. And, as Dick Gephardt said, to have a great debate, to reach great decisions, not through a civil war, not by bombing one of our regional capitals, not by killing a half million people, and not by having snipers. Let me say unequivocally, I condemn all acts of violence against the law by all people for all reasons. This is a society of law and a society of civil behavior. (108113)

In light of the April Oklahoma City bombing - "one of our regional capitals" - this passage takes on a possible interpretation that it did not have for most hearers at the time.

It may have been nothing more than a reference to a situation such as that of Bosnia. Words and phrases such as "civil war," "killing half a million people," and "snipers" seem to support this reading. However, at the time, none of these dangers seemed possible in the United States; nevertheless, this strong condemnation of violence includes explicit deictic references to the U.S. ("our," "this"). The last two sentences especially seem, in retrospect, to be stern warnings, especially as delivered. Now that it is known that politically 'rightwing' extremist militia groups and individuals have for some time been more widespread and more armed that most Americans had realized (most Americans did not even know of their existence), and that the Federal Building in Oklahoma City had long been targeted, it seems at least possible that Gingrich - knowing something that most of the general public did not know - was indeed trying to warn such extremists off. Even if this is the case - and it may not be - I do not mean to imply that Gingrich necessarily had knowledge of the plan that was put into effect in April, 1995 - merely that it now appears that there were several plans of this sort in the extreme rightwing community, and therefore it is not unreasonable that rumors might have reached him. 
- lexical choice (referring to antagonism), including: -pejorative words attributed to only one side

-metaphor

-explicit syntactic, cognitive, and discourse-iconic equations and oppositions

\section{TABLE 6}

Linguistic Mechanisms Evoking Gingrich's Frame 5:

The Fighter

In specifically political terms, references to 'bipartisanship', in its usual political-talk reading of 'cooperation', are built into the genre of the 'Speaker's inaugural' speech, just as they are into the presidential State of the Union address, and for much the same reason: they are delivered by a government official who is supposed to represent the whole of the American people, not just one political party.

In practice, of course, in the American two-party electoral system, this Frame 6 Cooperation between political parties that is conventionally represented by the term 'bipartisan' is set within an underlyingly adversarial framework. Gingrich's speech is no exception. Although his first line speaks (using conventional political language) of "my good friend, [Democratic congressional leader] Dick Gephardt," Gingrich introduces the Republican/ Democratic split of the last forty years in line 2. Furthermore, he clearly thinks that politics is a combat, although it cognitively does not have to be. (The relationship of politics to the groupings of conventional metaphors that represent competition and cooperation, and the cognitive and linguistic differences between activities that are inherently competitive or cooperative and those that are only, if frequently, construed as such, is something I have discussed elsewhere [Morgan 1993, 1994], and do not have space to discuss here). For example:

It is the most marvelous act of a complex giant country trying to argue and talk. (108-109)

(26) $[\mathrm{T}]$ his and the other body across the way [the Senate] are where freedom has to be fought out. (142-143)

Note the order of the verbs in example (25), and the implicit characterization in example (26) of the House and Senate as a necessary battleground, although without any explicit enemy, in an agentless passive that avoids assigning responsibility. The enemy is therefore presumably the other party, the Democrats.

In the following example, the two 'sides' are the Republicans and the leftists:

[E]very Member on both sides ... I say to those Republicans
... I would say to my friends on the left $(297-300)$

This is a very partisan equating of all Democrats with 'leftist' politics and a much more damaging label than the usual Republican collocation of 'liberal Democrat'. 'Leftist' is a very negative term for most Americans of both parties, and is not at all outweighed by the 
politically conventional "my friends."

In general, negative words are explicitly or implicitly associated with the Democrats, primarily through Gingrich's exploitation of his hearers' real-world knowledge that the Democrats have been in charge for forty years (as he reminded the hearers in line 2 ), and the Republican interpretation that therefore whatever has happened during those forty years ought to be attributed to them ("We [on the other hand] can find ways immediately to do things better," 284). The only two alternatives presented are the "humans" and the "bureaucracies" (302), and there is a collection of negatively evaluated lexical items that are used to talk about the current situation of children: "killed," "buried," "equal to slavery," "dead," "lost", "end up," "dumpsters," "doomed," "dangerous," and “jail” (258-269, 279-285).

Furthermore, Gingrich opposes the "welfare state" to the "opportunity society," as he has long done elsewhere, in a rather lengthy but not tightly focused passage (209-304) that includes the explicit statement of example (28) (also 209-210):

The welfare frame and its entailments and presuppositions are debatably positive or negative, with the judgment being closely linked to political parties, but those of "opportunity" are entirely positive. Exactly which actions and programs constitute "opportunity," however, is of course precisely the point at issue.

In a passage that precedes example (28), Gingrich the Cooperator (Frame 6, below) has already mentioned both the "liberal wing of the Democratic Party" and President Franklin Delano Roosevelt and explicitly associated them with two things whose 'goodness' no one disputes: "hope" for the nation and integration. He has also identified Reagan and today's Republicans with some kind of plan to deal with the current economic challenges, in the discussion of which the reference to the civil rights movement is embedded. Therefore, by a discourse iconic extension from the order of the collocation of "welfare" and "opportunity," the Democrats - mentioned first in the preceding passages are once more associated with the "welfare state" and therefore with the public housing projects and the deaths of children which are mentioned almost immediately following. The 'Republican-good, Democrat-bad' equations are further supported by the general American cultural preference for that which replaces as better than that which is replaced.

In the same way, it is the Republicans who are associated with the "opportunity society," with "find[ing] ways immediately to do things better" (284). In addition, Gingrich explicitly asks:

\footnotetext{
8 "End up" usually implies a negative evaluation of some part of the situation: a person may be in a good situation undeservedly ("He ended up in the White House despite his negative political advertising"), or the situation may be deserved but not good ("They finally caught her stealing and she ended up in jail"). Compare "Despite his college education, he endedup as a store clerk" (that is, there is implicit disapproval of this outcome) and "Despite his college education, he ended up as a store manager," which sounds somewhat odder. Perhaps this is because it implies that being a store manager should also be viewed disapprovingly as 'beneath' his educational level, a conclusion - unlike the store clerk situation - that is not always generally agreed upon in the U.S.
} 
How can we not insist that every day we take steps to do something? (263-265)

Who is the "we"? It could be "any American" (261, and in fact syntactically seems to be), but it is Americans following in the "steps" of the Republicans' "opportunity society" to end this "moral crisis" just as the Democrats previously "ended segregation" - acting either in flattering imitation of the Democrats or in usurpation of the moral ground, depending once again on one's assessment of Gingrich and the Republicans in general. Furthermore, this is not merely an option; it is something that we "must" do (in one of Gingrich's rare uses of "must," example [28]).

Since Gingrich never mentions specifically what any of the Democrats' 'negative' actions have been, there are no details to challenge his "welfare state" characterization of what the Democratic Party - especially its "liberal wing" - established.

\subsection{Pronouns}

Before going on to the next frame, a few additional words about Gingrich's use of pronouns, specifically his use of "we," are in order. In cases where the referent is clear, the "we" of Gingrich's speech almost always refers to the members of the House of Representatives (or to Congress as a whole) - at times explicitly differentiated from the rest of America:

(30) We have to reach out to the American people (305)

(31) We should insist that our success for America is felt in the neighborhoods, in the communities, is felt by real people living real lives (326-327)

This populist-based 'opposition' of Congress to the American populace is not necessarily untraditional, but it is not common in this genre because it is usually not very relevant: the Speaker's 'inaugural' speech is usually not broadcast to the wider American public. Usually, the audience is limited to the members of the House.

However, in this speech the referent of "we" is not always clear. In many of these cases the referent seems to be either the members of the House, which is traditional, or else the Republicans, but often it is not possible to decide which of these is meant. This may reflect Gingrich's own equation: the majority party is the House. In either case, his use of "we" is part of his adversarial cognitive model of American party politics (Frame 5, The Fighter).

\subsection{Frame 6: The Cooperator}

Frame 6, The Cooperator, can also be seen as one of the Traditional American Values (Frame 3). As Benjamin Franklin put it at the signing of the Declaration of Independence, "We must indeed all hang together, or, most assuredly, we shall all hang separately." See Table 7 for some markers of this frame: 
-genre conventions, including fixed phrases

•other lexical choice (e.g., "together," “all”)

-metaphor

\section{TABLE 7}

\section{Linguistic Mechanisms Evoking Gingrich's Frame 6: \\ The Cooperator}

References to Frame 6 in this speech are of two kinds: those dictated by the conventions of the genre ("my good friend, Dick Gephardt," 1, and several other positive references to Gephardt, passim), and, more often, those that are to a degree inherently negated by the already discussed adversarial presuppositions of Frame 5, The Fighter, such as "I think on a bipartisan basis" (221-222, 233-234, etc.). Near the end of the speech, Gingrich explicitly assigns priority to Frame 6 in this implicit frame clash: "I promise each of you that without regard to party my door is going to be open" (340-341).

A statement such as that in example (32) below is essentially a Frame 6 appeal to Frame 2, Frame 3, and American tradition in general, as reinforced by the introduction of the "commoners" theme at the beginning of the utterance. The use of "to some extent" to weaken the mention of partisan politics can be read either as an honest appeal to Cooperation or as a deflection of the issue of partnership in favor of the less demanding appeal to American tradition:

(32) Here we are as commoners together, to some extent Democrats and Republicans, to some extent liberals and conservatives, but Americans all. (114-115)

The appeal at the end of the speech (358-363, example [24]) is conventional, and also makes a similar appeal to Frame 3.

A clearer evoking of the spirit of cooperation would have resulted from a more frequent use of the more neutral but certainly less conventional word "nonpartisan," which lacks the reminder of the existence of the Democrats (although it does imply the existence of one or more unspecified party or parties) and therefore does not reinforce the perception of an adversarial situation. A person can be without any party affiliation at all and be called 'nonpartisan'. The use of this word would also have been consistent with the Republicans' emphasis on 'less government'. However, "nonpartisan" is used by Gingrich only once, and that nearly at the end of the speech (339-340).

Within the American political framework, of course, as already discussed, the term 'bipartisan' is conventionally understood as emphasizing not the adversarial underpinnings, but rather Cooperation and "working together" (e.g., 346). Gingrich also speaks of creating "a partnership" (305) but it is hard to see clearly who the partners are intended to be. They might be Democrats and Republicans, or they might be Congress and the rest of America. Since he goes on to use the word "bipartisan" several times, he probably means the two parties, but the utterance that intervenes between the "partnership" and the "bipartisan"ship makes the identification less certain. 


\subsection{Frame 7: The Visionary}

The scarcity of markers of Frame 7 in this speech is surprising, considering its inaugural context as a 'beginning' speech and especially given Gingrich's other speeches, statements, and books, evidence of his longstanding interest in 'futurism' from at least the 1970s to the present (see, e.g., Wills 1995). For example, he wrote the foreword to Creating a new civilization (1995) by futurists Alvin and Heidi Toffler, many of whose ideas he has long espoused (e.g., Wills 1995: 4, Bruck 1995). (Alvin Toffler wrote the popularly influential books Future shock [1970] and The third wave [1980].) Table 8 lists the two types of linguistic markers of this frame that are seen in this speech:

\begin{tabular}{ll}
\hline & $\bullet$ lexical choice \\
$\bullet$ propositions about the future \\
\hline
\end{tabular}

TABLE 8

Linguistic Mechanisms Evoking Gingrich's Frame 7:

The Visionary

Except for the frequent use of the word "hope" (which also belongs to Frame 3 [The Spokesman for Traditional American Values]), only a few markers of Frame 7 are present. They include the phrases "transforming, not just cutting" (219), "preparing . . . a better future" (362-363), "the right sense of where we have to go as Americans" (257), and the following passage late in the speech:

(33) This ought to be the goal that we go home and we tell people we believe in: that there will be a Monday morning when for the entire weekend not a single child was killed anywhere in America; that there will be a Monday morning when every child in the country went to a school that they and their parents thought prepared them as citizens and prepared them to compete in the world market; that there will be a Monday morning where it was easy to find a job or create a job, and your own Government did not punish you if you tried. (319324)

This passage also has links to Frame 3 (The Spokesman for Traditional Values: protecting our children, being good citizens, having a job), Frame 4 (The [Authoritarian] Leader: we set the goals), Frame 5 (The Fighter: by our real-world knowledge that "your own Government" refers to the Democratically controlled years), and Frame 6 (The Cooperator: by viewing the referent of "we" as the entire Congress). It is therefore appropriate for the concluding section of the speech.

\section{Self-presentation: 'More is better' and metonymy}

Let us now take a brief look at two principles that seem to affect Gingrich's language on several levels regardless of frame: the concept that 'more is better' and the use of metonymy. 


\section{1. 'More is better'}

In line with his several frame-related violations of the Maxim of Quantity (already discussed), Gingrich instantiates the metaphor that 'more is better' on several levels. For example, his speech is much longer than the others in the comparison group. ${ }^{9}$ It requires nearly twelve columns in the Congressional record, as opposed to 5.5 columns (Foley 1989), 5+ columns (Martin 1947), 4.75 columns (Wright), 2.75 columns (Martin 1953), 2 columns (O'Neill, Albert, Foley 1993), and slightly more than 1 column (Rayburn).

In like fashion, previous Speakers present only one or two American quotations or references in their inaugural speeches (except for Albert, who had four); Gingrich has six. In one of the traditional sections of the 'Speaker's inaugural speech' genre (namely, the introduction), Wright (1987) thanked his colleagues, his predecessors, his wife, and their four children; in 1989, in a style reminiscent of contemporary televised entertainment awards, Foley thanked his constituents, mentors, and predecessors as Speaker, his staff, teachers, and friends, and his wife, mother, sister, and father. Gingrich thanks his predecessors, the "House officers," long-serving Republican Congressmen, and his mother, his father, his daughters, their husbands, his wife, his three nieces and his three nephews $(17-26,45-64 / 68)$.

Another traditional part of the introduction is the mention of those of the Speaker's family and friends who are present in the House chamber. Again Gingrich extends the section, mentioning by name his "Mom" and "Dad," his daughters and their husbands, his present wife, and the "very large extended family between Marianne and me," including some of his nephews and nieces, mentioned by name and age (60-77).

Lexically, Foley uses "bipartisan" once or twice in his speech; Gingrich uses the word three times within just one passage. Certain evaluative adjectives (especially superlatives in form or sense, such as "great," 13-16, cf. 33) are repeated by Gingrich many times. "Overwhelmed"/"overwhelming" appears seven times in one passage (27-33; the early repetitions are in clauses which balance each other rhetorically). Taken singly, these adjectives can be seen as modest: in the light of so much history and tradition, who could help but feel overwhelmed? Conversely, especially when taken in connection with the multiple uses of "I" already discussed, they can be seen as reinforcing an impression of 'ego'-centricity. Once again, one's preferred interpretation can owe as much to the personal views that the hearer brings to the speech as to anything contributed decisively by the language.

One more-is-better-related detail of Gingrich's speech that might at first seem completely idiosyncratic in fact is not. This is his reference to his gavels (34-38): he has two, not just one, and one of them is not only new but larger than usual. This episode (related also to Frames 2 and 4) provided a 'sound bite' for some of the media coverage, and the irony of the situation is worth noting, since the only other speaker in the sample to mention such a large gavel was Wright. In the late 1980s Gingrich was highly instrumental in removing Wright from the Speakership (see, e.g., Barry 1989), primarily on the grounds

\footnotetext{
${ }^{9}$ Gingrich's speech was compared to eight previous 'Speaker's inaugural' speeches: two by the last Republican Speaker before Gingrich, Joseph W. Martin, Jr. (1947, 1953) and at least one by the most important Democratic Speakers since Martin, namely, Sam Rayburn (1961), Carl Albert (1971), Thomas P. (“Tip”) O’Neill, Jr. (1977), Jim Wright (1987), and Tom Foley (1989, 1993).
} 
of ethics violations involving publication of a book in a situation that many of Gingrich's critics have publicly considered to be similar to an arrangement made by Gingrich himself.

\subsection{Metonymy}

Gingrich uses metonymy - here, evoking an entire semantic domain or frame by the explicit expression of one element belonging to it - to move within one frame and from one frame to another, making use of only the broadest and most general linkages even at the cost of nuanced connections and polished transitions. For example, he moves (139-146 ff.) from "freedom" (Frame 3) and "tradition" (Frame 3) and "work" (Frames 2 and 3) to religion ("a bipartisan prayer service," Frame 3) and "moral problems" (Frame 3), and so on. The repeated transitions in this passage from secular aspects of Frame 3 to religious aspects and vice versa are movements from one subframe to another, with the connections being nothing more than the fact that the very broad category of Traditional American Values (Frame 3) includes them all.

Such a broad category has very emotional evocative power and unity at one level, as we have seen, but when we begin to look at the details we see a variety of subcategories. Although each subcategory has a different experiential frame - such as the experiential frame of 'attending a worship service' and that of 'working at a job' - Gingrich ignores them, relying on metonymy within the larger frame to supply the connections. It does, but not without a certain potentially jarring effect at times (e.g., the transition at 143-144).

This use of metonymy also similarly results at times in a lack of precision. In the explication of the de Tocqueville passage already discussed (example [1], it was noticed that he chose one word - "vulgar" - from a semantic field of adjectives meaning roughly 'common/populist' or by extension 'undistin-guished', even though the word "vulgar" did not actually appear in the quotation. As we have seen, this contradicts the Professor frame, since professors are supposed to be precise with respect to their facts; however, at the same time it reinforces Frame 2, Just Plain Folks.

Similarly, at another point in the speech he moves from "commoners" (114, Frame 2 ) to 'great American figures' such as Lincoln and Franklin Roosevelt (115-117, Frame 3; intersecting with particularly salient examples of Frame 4 Leaders) to "a great country of great people" (118). This last phrase can be seen as belonging to both Frame 2 and Frame 3 , or to either Frame 2 or Frame 3 alone, depending on which antecedent the audience understands for "great people" - the "commoners" (perhaps slightly preferred) or the important presidents or both. Here, Gingrich can in fact appeal to two frames simultaneously by specifying neither.

Thus, in a larger sense, Gingrich's use of metonymy serves to form part of the political balancing act between clashing frames that is a large part of elected officials' attempts to appeal to as many facets of the American cultural tradition - and therefore as many constituents - as they can, within the beliefs and principles of their own political ideologies.

This kind of imprecise 'frame metonymy' is found as a feature of Gingrich's style in statements outside this speech as well. For several examples related to American history, such as misrepresenting Thomas Jefferson's words in the Declaration of Independence (more than once), and for a movie example, see Wills 1995: 6-7. 


\section{The orphanage passage: Frames, face, and pragmatics}

(9) [A]nd we got into what I think frankly has been a pretty distorted and cheap debate over orphanages (273-274)

Let me say, first of all, my father, who is here today, was a foster child. He was adopted as a teenager. I am adopted. We have relatives who are adopted. We are not talking out of some vague impersonal Dickens "Bleak House" middle-class intellectual model. We have lived the alternatives. (275-278)

"Frankly" in the immediately preceding passage (example [9], repeated above) has set the frame: one of plain speaking, of hard truths.

Gingrich begins with "Let me say." By this phrase a speaker ostensibly asks indirectly for permission to speak, or at least for ratification of his/her turntaking and implicitly of the content of the utterance, but of course in actual usage this construction is not really any sort of indirect request. No one ever pauses afterwards to wait for a reply. Instead, what the phrase really signals is a coming statement that is often less than fully acceptable in some way but that carries some degree of emphasis. It signals the speaker's expectation of opposition on the part of the hearers, which the speaker is (courageously) disregarding in stating the 'necessary truth'. Here Gingrich is setting up an important part of his argument: that he knows about adoption and orphanages, but his critics do not.

"[F]irst of all," Gingrich says, his father was a foster child and was adopted. Secondly, Gingrich himself was adopted. Thirdly, he has "relatives who were adopted." That is, he is trying to make his argument stronger by an appeal to weight of numbers 'more is better'.

Technically Newt Gingrich was in fact adopted by his stepfather. However, he is misapplying the technicality. The outcry over his comments about orphanages had to do with removing children from 'welfare mothers', but Gingrich's situation was very different. It was non-stereotypical for the terms of the political argument: he was adopted by the man who married his birth mother.

Furthermore, orphanages and adoption are not exactly the same thing in any case. It is true that both situations prototypically involve children who are not living with and being raised by their biological parents - but the resemblance ends there. Because of this degree of similarity, however, the hearers may accept Gingrich's metonymic version of Relevance.

The phrase "some vague impersonal Dickens [not the more 'correct', Frame 1 "Dickensian"] 'Bleak House' middle-class intellectual model" is emotionally evocative and was delivered with intonational force. The constructions "we are not talking about" and "some vague" usually indicate irritation on the part of the speaker and will probably therefore arouse either indignant agreement or corresponding irritation on the part of the hearers, especially if accompanied, as it was here, by an appropriately nuanced intonation. His statements are at first short and punchy, followed by an accumulating series of pejoratively-intended adjectives. "Vague," i.e., not forceful, is pejorative in Frame 4 (The [Authoritarian] Leader) and also evokes 'ivory-tower intellectuals' and 'absent-minded professors', Frame 1 stereotypes that are laughable to the Just Plain Folks of Frame 2. (The 
laughter may be either affectionate or malicious.) "Impersonal" is pejorative in Frame 3 (The Spokesman for Traditional American Values). "Middle-class" is often pejorative in Frame 1 (The Professor); this evaluation clashes with 'middle-class' as 'typical' and desirable in Frames 2 and 3. "Intellectual" is pejorative in Frame 2 (Just Plain Folks). The 'Dickens frame' includes all of Dickens' novels and may have triggered the "middle-class intellectual" collocation, since a stereotypical view of Dickens might comprise both adjectives. By subject matter and sympathies, the Dickens frame evokes the Just Plain Folks frame; by virtue of the status of Dickens' novels as classics, it evokes the Professor frame.

Looked at one way, this is a self-presentation frame clash; looked at another way, it is an inspired way to appeal to two audiences by means of a single non-selfpresentational frame.

It is by metonymy - whether consciously or not - that Gingrich refers to the adoption in Bleak House rather than the orphanage in Oliver Twist. Although the latter would perhaps be a more literally appropriate reference given the wider context of the political argument, it would not serve as a very good argument for his support of orphanages. In one sense, then, this metonymic displacement might somewhat undercut his self-presentation as a Professor, but it makes much more sense given his political agenda. In addition, if because of metonymy the frame itself is more important than the precise mapping of its elements, there is in fact no problem. "Bleak" is, after all, certainly the proper adjective to describe the stereotypical image of an orphanage which he is trying to refute via his adoption argument - rather more than "Oliver" or "Twist," both of which may also sound amusing to Americans.

Note that except for "bleak" the adjectives in this list are not necessarily pejorative. They receive that interpretation from the construction and the intonation, as well as from certain background ideologies, including current well-publicized Republican associations of 'liberals' with 'elites', especially in the media and at universities, and therefore transitively with "intellectuals," reinforced by the already mentioned American tradition of anti-intellectualism.

There is, however, no recognition by Gingrich that this pejorative use of "intellectual" might seem odd when spoken by a person who employs Frame 1 for selfpresentation. Similarly, given Frame 2 (Just Plain Folks), the pejorative use of "middleclass" also seems odd, since the middle class has traditionally been viewed as the stable foundation of American society and the prototypical repository of the essential American values (Frame 3). Furthermore, the collocation of "middle-class" and "intellectual" applied to the same NP is also odd, since usually (at least outside of a Dickens frame) the two are stereotypically incompatible.

\section{Frame clashes}

Many of the frames are coherent with one another - such as The Professor, The Spokesman for Traditional American Values (special case, American history), and The (Authoritarian) Leader; or Just Plain Folks and The Spokesman for Traditional American Values - but some are not. In the orphanage passage, for example, as we have seen, the Professor frame conflicts with the Just Plain Folks frame, and The (Authoritarian) Leader (at least when 
viewed negatively) clashes with The Cooperator.

Gingrich also causes frame clashes, and a sense of stylistic mismatch, by his use of markers of both formal and informal register even within the same passage. This is seen often in the speech (e.g., 5-6: Frame 1, the more 'correct' but less common "people decides" instead of the more common American "people decide," Frame 2, "so"; 209: Frame 1, "truly," Frame 2, the prescriptively proscribed 'split infinitive' of "to truly replace"). In the following example, the quotation and citation, the content, and the purpose are Frame 1 (Professorial and didactic), but much of the extremely colloquial syntax and lexical choice belongs very strongly to Frame 2 (Just Plain Folks):

$\mathrm{He}$ [author Morris Schectman] draws a distinction between caring and caretaking .... He said caretaking is when you bother me a little bit, and I do enough... "If you will quit drinking, I will help you get a job."... "I feel better. I gave him a buck or 5 bucks."

We are reminded here of example (1), where Gingrich the Professor quotes from Tocqueville (whose style now sounds formal), then explains it (a Professorial activity) with a Just Plain Folks syntax and pronoun choice ("you," 97-106).

Sometimes the frame clashes serve the same pragmatic political purpose as the frame ambiguities, allowing Gingrich to appeal to more than one constituency at one time. Other frame discrepancies have been resolved culturally in the United States (although not explicitly in this speech) by invoking intersecting subframes in which the discrepancy does not exist. An American can be both a Fighter (Frame 5) and a Cooperator (Frame 6), for example, by cooperating with others of Us to fight against Them. Similarly, one can Fight for one's Vision (Frames 5 and 7) or for Traditional American Values (Frames 3 and 5), or speak for both Traditional American Values and for Vision (Frames 3 and 7) not only by speaking of hope but by claiming to be taking traditional values into the future (as Gingrich often claims).

\section{Conclusion}

Gingrich's 1995 version of the 'Speaker's inaugural' speech offers little in structure that does not appear in previous speeches of this genre, although most elements are extended beyond those in the 'inaugural' speeches of previous Speakers via a 'more is better' metaphor that appears in other aspects of Gingrich's speech as well. This speech is also very representative of how he usually chooses to portray himself both to his colleagues in the Congress and to a wider audience, and relies on several of his longstanding, favorite themes and slogans (e.g., "The Opportunity Society"). His allusions to American political leaders of the past, for example, are simultaneously traditional elements of the genre and part of his frames of self-presentation.

These self-presentation frames involve both convention and deliberate choice. The frames are not his alone; they are rooted deeply in American culture in general and American political culture in particular. Experienced politicians know which frames to appeal to for desired effects, and which linguistic markers to use to evoke each frame. After a long time in politics, much of this surely becomes almost instinctive, but other examples in this speech (such as the allusions to Franklin Roosevelt) are most likely 
included by design.

All seven of the frames in this paper, as well as others found in American culture but not discussed here, are characterized and recognized using the same types of linguistic markers, as Tables 2 through 8 show. Lexical choice is one of the most basic, most obvious, and most effective ways to invoke a frame, as are other indicators of register (especially important for Frames 1 and 2, The Professor and Just Plain Folks) such as more or less informal syntax. Other markers include allusions and frame-specific fixed phrases.

In this speech, Gingrich presents himself both as a man of authority and leadership (Frames 1, The Professor; 3, The Spokesman for Traditional American Values; 4, The [Authoritarian] Leader; 7, The Visionary), and as a man of the people (Frames 2, Just Plain Folks; 3, The Spokesman for Traditional American Values; to some extent also Frame 7, The Visionary, via Frame 3). This double stance is a core part of the American political tradition; Gingrich's use of it offers yet another indication that he is aware that unlike his predecessors as Speaker his audience includes the wider American populace.

There are many overlaps, in varying degrees, of content and therefore of linguistic markers among the frames. For example, the overlap between Frame 2 (Just Plain Folks) and Frame 3 (The Spokesman for Traditional American Values) is considerable; that between Frame 7 (The Visionary) and Frame 3 (The Spokesman for Traditional American Values) is much less. Looked at in another way, Frames 2, 3, and to a lesser extent 5, 6, and 7, are part of a larger "Ideal American" frame cluster.

Frames may also clash with one another. For example, the Professor of Frame 1 and the Just Plain Folks of Frame 2 are often at odds over the value of higher education in the 'ivory tower', especially as compared to 'common sense' in the 'real world'. Perhaps because the Republican party has usually been much less concerned about coalitionbuilding among America's multiple constituencies than are the Democrats, Gingrich does not attempt to reconcile these opposing frames directly. ${ }^{10}$ Sometimes, instead, he removes the clash by calling up a non-self-presentational cultural frame that has a place in both, such as the "Dickens" frame in the orphanage passage (see example [34]).

In other passages, he simply uses them both in close proximity. Sometimes he merely moves quickly from one frame to another, as in examples (1) and (35). ${ }^{11}$ At other

\footnotetext{
${ }^{10}$ There are, however, some remarks that are designed to appeal to black Americans in particular, either explicitly (praise of the Civil Rights Movement, 242-243; a breakfast with two members of the Congressional Black Caucus, 266-269; a reference to and quotation from "The Battle Hymn of the Republic," 329-332, 338339 ) or implicitly (the tragedy of children killing children in "a public housing project in Chicago," 258-259; cf. 334-337). During and after the 1996 presidential election campaign, the Republicans began to make direct overtures to the African American community: the black Congressman J.C. Watts of Oklahoma was an important speaker at the GOP nominating convention in 1996 and made the official Republican television response to President Clinton's 1997 State of the Union address; 1996 Republican vice-presidential nominee Jack Kemp campaigned in New York City's Harlem and other inner-city black communities.

${ }^{11}$ Gingrich uses this method in other texts, e.g., To renew America (33): "It is stunning ['more is better'] to immerse yourself [Frame 2] in the visionary [Frame 7] world of the American experience [Frame 3] - to listen, for example, to Lincoln [Frame 3] raising cheers from white working-class [Frame 2] audiences about Negro [sic] slaves' inherent right to keep the fruits of their own labor [perhaps Frame 1] - and then to realize how much of this slef-confidence and pride in our own accomplishments [Frame 3] has been lost. We have gone from being a strong, self-reliant, vigorous society [Frame 3] to a pessimistic one that celebrates soreheads and losers jealous of others' successes [an opposition that perhaps evokes Frame 5]."
} 
times, he allows one - usually but not always the Just Plain Folks frame (Frame 2) or the closely related Spokesman for Traditional American Values frame (Frame 3) - to dominate, for reasons of his political agenda. Similarly, he allows referents of pronouns, especially of "we," to shift among frames, thus evoking more than one together.

It is not only Gingrich's use of the pronoun "we," however, that is open to almost opposite interpretations, usually depending on the hearers' politics. As we have seen, his frequent "I + verb" constructions, for example, are interpretable as either markers of Authority (Frames 1 and 4) or humility (Frames 2 and 3), and the antecedent of "great people" in line 118 can be understood as the Frame 2 "commoners" or the Frames 3 and 4 'great American presidents' or, usefully, both. These ambiguities do not necessarily persuade people to change their minds and support him or his political goals, since those who disagree with him will generally choose the negative interpretations, but they do make it harder for his opponents to find passages that can be unequivocally challenged.

He is also skilled at evoking just enough of a frame to allow his partisans to infer the rest, without committing himself explicitly to the full frame. For example, near the end of the speech (313-343, example [20]), he uses language that suggests two subframes: the friend or colleague (who will "listen" and "work with each of you") and the therapist (who also listens and works, although in a marked way). However, neither of these subframes is completely evoked by the language, so that Gingrich fully makes neither the personal commitments of a friend nor the professional commitments of a therapist.

Whether for political or personal reasons, Gingrich does not remain long 'in' any one frame. On the negative side, this constant shifting of frames of self-presentation helps lead to a somewhat chaotic speech in terms of thematic organization, since Gingrich does not take advantage of the overlaps and linkages to structure the overall text. Furthermore, the overlaps can easily justify some transitions within frames and from one frame to another, but in his metonymic fashion Gingrich is often content with links that are appropriate only at the most general level (e.g., within Frame 3 at lines 115 to 117), resulting at times in transitions that are only loosely connected.

Finally, how useful is this speech to the wider Republican agenda? For an opponent, the speech raises enough semantic and pragmatic questions to confirm a negative opinion of the Speaker and the Republican goals, reinforced by the authoritarian strain that underlies many of the frames; the appeals to cooperation and compassion will be interpreted as little more than a conventional facade full of carefully worded loopholes. A supporter, however, will accept the collection of frames, resolve the semantic and pragmatic clashes and ambiguities in Gingrich's favor, and from background knowledge fill in the framework of an agenda presented explicitly only in allusions and generalities.

The frames seen in this speech are thus constructed from and construct American political and general culture. They offer the support of a conventionally shared understanding between speaker and hearer, and a way to direct implicatures without the continual need for explicitness and consequent responsibility. Although an unexpressed or perhaps even consciously unrecognized sense of frequent frame clashes or ambiguities in a politician's language may contribute to a sense of mistrust or dislike on the part of at least some of the electorate, there is in much of this speech also a considerable amount of linguistic room for either a positive or a negative interpretation of Gingrich as he presents himself - and that, of course, is one of the useful abilities of a politician. 


\section{References}

Barry, John M. (1989) The ambition and the power: The fall of Jim Wright. New York: Viking.

Bruck, Connie (1995) The politics of perception. New Yorker (October 9): 50-77.

Campbell, Karlyn Kohrs, and Kathleen Hall Jamieson (1990) Deeds done in words: Presidential rhetoric and the genres of governance. Chicago and London: University of Chicago Press.

Erickson, Paul D. (1985) Reagan speaks: The making of an American myth. New York and London: New York University Press.

Gingrich, Newt[on L.] (1995) To renew America. New York: HarperCollins.

Gingrich, Newt[on L.] (1996) The Speeches of Newton L. Gingrich, Speaker of the United States House of Representatives. World Wide Web (accessed February 1996): http://dolphin.gulf.net/Gingrich. (Off-air tape: National Public Radio live broadcast, January 4, 1995.)

Gingrich, Newt[on L.], Dick Armey, and the House Republicans (ed. Ed Gillespie and Bob Schellhas) (1994) Contract with America: The bold plan by Rep. [sic] Newt Gingrich, Rep. Dick Armey and the House Republicans to change the nation. New York: Times Books/Random House. (Advertisement in TV Guide: week of October 22-28, 1994.)

Goffman, Erving (1974/1986) Frame analysis: An essay on the organization of experience. Boston: Northeastern University Press.

Hofstadter, Richard (1963) Anti-intellectualism in American life. New York: Knopf.

Jamieson, Kathleen Hall (1988) Eloquence in an electronic age: The trans-formation of political speechmaking. Oxford: Oxford University Press.

Johnson, Haynes (1991) Sleepwalking through history: America in the Reagan years. New York, etc.: Doubleday/Anchor Books.

Lakoff, George (1987) Women, fire, and dangerous things: What categories reveal about the mind. Chicago and London: University of Chicago Press.

Lakoff, George (1996) Moral politics: What conservatives know that liberals don't. Chicago and London: University of Chicago Press.

Lakoff, Robin Tolmach (1980) How to look as if you aren't doing anything with words: Speech act quantification. VS. (Versus) 26/27: 29-47.

Lakoff, Robin Tolmach (1990) Talking power: The politics of language. New York: Basic Books.

Morgan, Pamela S. (1993) Metaphorical families I: Competition. Unpublished ms.

Morgan, Pamela S. (1994) Metaphorical families II: Cooperation. Unpublished ms.

Toffler, Alvin, and Heidi Toffler (1995) Creating a new civilization: The politics of the Third Wave. Atlanta: Turner Publishing.

United States House of Representatives. Congressional record: 80th Congress (First Session) (January 3-February 24, 1947) (Martin). 
83rd Congress (First Session) (January 3, 1953-February 25, 1953) (Martin).

87 th Congress (First Session) (January 3-January 26, 1961) (Rayburn).

92nd Congress (First Session) (January 21-February 1, 1971) (Albert).

95th Congress (First Session) (1977) (O’Neill).

100th Congress (First Session) (1987) (Wright).

101 st Congress (First Session) (1989) (Foley).

103rd Congress (First Session) (1993) (Foley).

104th Congress (First Session) (1995) (Gingrich).

Warner, Judith, and Max Berley (1995) Newt Gingrich: Speaker to America. New York, etc.: Signet/Penguin Books USA.

Wills, Garry (1995) The visionary. New York Review of Books 42: 5 (March 23): 4-8.

\title{
APPENDIX: The Text of the Speech
}

Source: World Wide Web (line breaks changed and numbers added). Also available in the Congressional Record; broadcast on some television and radio stations at the time of delivery.

\author{
NEWTON L. GINGRICH \\ Speaker of the United States House of Representatives \\ "Inauguration Speech," January 4, 1995
}

Let me say first of all that I am deeply grateful to my good friend, Dick Gephardt. When my side maybe overreacted to your statement about ending 40 years of Democratic rule, I could not help but look over at Bob Michel, who has often been up here and who knows that everything Dick said was true. This is difficult and painful to lose, and on my side of the aisle, we have for 20 elections been on the losing side. Yet there is something so wonderful about the process by which a free people decides things.

In my own case, I lost two elections, and with the good help of my friend Vic Fazio came close to losing two others. I am sorry, guys, it just did not quite work out. Yet I can tell you that every time when the polls closed and I waited for the votes to come in, I felt good, because win or lose, we have been part of this process.

In a little while, I am going to ask the dean of the House, John Dingell, to swear me in, to insist on the bipartisan nature of the way in which we together work in this House. John's father was one of the great stalwarts of the New Deal, a man who, as an FDR Democrat, created modern America. I think that John and his father represent a tradition that we all have to recognize and respect, and recognize that the America we are now going to try to lead grew from that tradition and is part of that great heritage.

I also want to take just a moment to thank Speaker Foley, who was extraordinarily generous, both in his public utterances and in everything that he and Mrs. Foley did to help Marianne and me, and to help our staff make the transition. I think that he worked very hard to reestablish the dignity of the House. We can all be proud of the reputation that he takes and of the spirit with which he led the speakership. Our best wishes go to Speaker and Mrs. Foley.

I also want to thank the various House officers, who have been just extraordinary. I want to say for the public record that faced with a result none of them wanted, in a situation I suspect none of them expected, that within 48 hours every officer of this House reacted as a patriot, worked overtime, bent over backwards, and in every way helped us. I am very grateful, and this House I think owes a debt of gratitude to every officer that the Democrats elected 2 years ago.

This is a historic moment. I was asked over and over, how did it feel, and the only word that comes close to adequate is overwhelming. I feel overwhelmed in every way, overwhelmed 
by all the Georgians who came up, overwhelmed by my extended family that is here, overwhelmed by the historic moment. I walked out and stood on the balcony just outside of the Speaker's office, looking down the Mall this morning, very early. I was just overwhelmed by the view, with two men I will introduce and know very, very well. Just the sense of being part of America, being part of this great tradition, is truly overwhelming.

I have two gavels. Actually, Dick happened to use one. Maybe this was appropriate. This was a Georgia gavel I just got this morning, done by Dorsey Newman of Tallapoosa. He decided that the gavels he saw on TV weren't big enough or strong enough, so he cut down a walnut tree in his backyard, made a gavel, put a commemorative item on it, and sent it up here.

So this is a genuine Georgia gavel, and I am the first Georgia Speaker in over 100 years. The last one, by the way, had a weird accent, too. Speaker Crisp was born in Britain. His parents were actors and they came to the United States-a good word, by the way, for the value we get from immigration.

Second, this is the gavel that Speaker Martin used. I am not sure what it says about the inflation of Government, to put them side by side, but this was the gavel used by the last Republican Speaker.

I want to comment for a minute on two men who served as my leaders, from whom I learned so much and who are here today. When I arrived as a freshman, the Republican Party, deeply dispirited by Watergate and by the loss of the Presidency, banded together and worked with a leader who helped pave the way for our great party victory of 1980 , a man who just did a marvelous job. I cannot speak too highly of what I learned about integrity and leadership and courage from serving with him in my freshman term. He is here with us again today. I hope all of you will recognize Congressman John Rhodes of Arizona.

I want to say also that at our request, the second person was not sure he should be here at all, then he thought he was going to hide in the back of the room. I insisted that he come on down front, someone whom I regard as a mentor. I think virtually every Democrat in the House would say he is a man who genuinely cares about, loves the House, and represents the best spirit of the House. He is a man who I studied under and, on whom I hope as Speaker I can always rely for advice. I hope frankly I can emulate his commitment to this institution and his willingness to try to reach beyond his personal interest and partisanship. I hope all of you will join me in thanking for his years of service, Congressman Bob Michel of Illinois.

I am very fortunate today. My Mom and my Dad are here, they are right up there in the gallery. Bob and Kit Gingrich. I am so delighted that they were both able to be here. Sometimes when you get to my age, you cannot have everyone near you that you would like to have. I cannot say how much I learned from my Dad and his years of serving in the U.S. Army and how much I learned from my Mother, who is clearly my most enthusiastic cheerleader.

My daughters are here up in the gallery, too. They are Kathy Lovewith and her husband Paul, and Jackie and her husband Mark Zyler. Of course, the person who clearly is my closest friend and my best adviser and whom if I listened to about 20 percent more, I would get in less trouble, my wife Marianne, is in the gallery as well.

I have a very large extended family between Marianne and me. They are virtually all in town, and we have done our part for the Washington tourist season. But I could not help, when I first came on the floor earlier, I saw a number of the young people who are here. I met a number of the children who are on the floor and the young adults, who are close to 12 years of age. I could not help but think that sitting in the back rail near the center of the House is one of my nephews, Kevin McPherson, who is 5. My nieces Susan Brown, who is 6, and Emily Brown, who is 8 , and Laura McPherson, who is 9, are all back there, too. That is probably more than I was allowed to bring on, but they are my nieces and my nephews. I have two other nephews a little older who are sitting in the gallery.

I could not help but think as a way I wanted to start the Speakership and to talk to every Member, that in a sense these young people around us are what this institution is really all about. Much more than the negative advertising and the interest groups and all the different things that make politics all too often cynical, nasty, and sometimes frankly just plain miserable, what makes politics worthwhile is the choice, as Dick Gephardt said, between what we see so tragically on the evening news and the way we try to work very hard to make this system of free, 
representative self-government work. The ultimate reason for doing that is these children, the country they will inherit, and the world they will live in.

We are starting the 104th Congress. I do not know if you have every [sic] thought about this, but for 208 years, we bring together the most diverse country in the history of the world. We send all sorts of people here. Each of us could find at least one Member we thought was weird. I will tell you, if you went around the room the person chosen to be weird would be different for virtually every one of us. Because we do allow and insist upon the right of a free people to send an extraordinary diversity of people here.

Brian Lamb of C-SPAN read to me Friday a phrase from de Tocqueville that was so central to the House. I have been reading Remini's biography of Henry Clay and Clay, as the first strong Speaker, always preferred the House. He preferred the House to the Senate although he served in both. He said the House is more vital, more active, more dynamic, and more common.

This is what de Tocqueville wrote: 'Often there is not a distinguished man in the whole number. Its members are almost all obscure individuals whose names bring no associations to mind. They are mostly village lawyers, men in trade, or even persons belonging to the lower classes of society.'

If we include women, I do not know that we would change much. But the word 'vulgar' in de Tocqueville's time had a very particular meaning. It is a meaning the world would do well to study in this room. You see, de Tocqueville was an aristocrat. He lived in a world of kings and princes. The folks who come here do so by the one single act that their citizens freely chose them. I do not care what your ethnic background is, or your ideology. I do not care if you are younger or older. I do not care if you are born in America of if you are a naturalized citizen. Everyone of the 435 people have equal standing because their citizens freely sent them. Their voice should be heard and they should have a right to participate. It is the most marvelous act of a complex giant country trying to argue and talk. And, as Dick Gephardt said, to have a great debate, to reach great decisions, not through a civil war, not by bombing one of our regional capitals, not by killing a half million people, and not by having snipers. Let me say unequivocally, I condemn all acts of violence against the law by all people for all reasons. This is a society of law and a society of civil behavior.

Here we are as commoners together, to some extent Democrats and Republicans, to some extent liberals and conservatives, but Americans all. Steve Gunderson today gave me a copy of the 'Portable Abraham Lincoln.' He suggested there is much for me to learn about our party, but I would also say that it does not hurt to have a copy of the portable F.D.R.

This is a great country of great people. If there is any one factor or acts of my life that strikes me as I stand up here as the first Republican in 40 years to do so [sic]. When I first became whip in 1989, Russia was beginning to change, the Soviet Union as it was then. Into my whip's office one day came eight Russians and a Lithuanian, members of the Communist Party, newspaper editors. They asked me, 'What does a whip do?'

They said, 'In Russia we have never had a free parliament since 1917 and that was only for a few months, so what do you do?'

I tried to explain, as Dave Bonior or Tom DeLay might now. It is a little strange if you are from a dictatorship to explain you are called the whip but you do not really have a whip, you are elected by the people you are supposed to pressure-other members. If you pressure them too much they will not reelect you. On the other hand If you do not pressure them enough they will not reelect you. Democracy is hard. It is frustrating.

So our group came into the Chamber. The Lithuanian was a man in his late sixties, and I allowed him to come up here and sit and be Speaker, something many of us have done with constituents. Remember, this is the very beginning of perestroika and glasnost. When he came out of the chair, he was physically trembling. He was almost in tears. He said, 'Ever since World War II, I have remembered what the Americans did and I have never believed the propaganda. But I have to tell you, I did not think in my life that I would be able to sit at the center of freedom.'

It was one of the most overwhelming, compelling moments of my life. It struck me that something I could not help but think of when we were here with President Mandela. I went over 
and saw Ron Dellums and thought of the great work Ron had done to extend freedom across the planet. You get that sense of emotion when you see something so totally different than you had expected. Here was a man who reminded me first of all that while presidents are important, they are in effect an elected kingship, that this and the other body across the way are where freedom has to be fought out. That is the tradition I hope that we will take with us as we go to work.

Today we had a bipartisan prayer service. Frank Wolf made some very important points. He said, 'We have to recognize that many of our most painful problems as a country are moral problems, problems of dealing with ourselves and with life.'

He said character is the key to leadership and we have to deal with that. He preached a little bit. I do not think he thought he was preaching, but he was. It was about a spirit of reconciliation. He talked about caring about our spouses and our children and our families. If we are not prepared to model our own family life beyond just having them here for 1 day, if we are not prepared to care about our children and we are not prepared to care about our families, then by what arrogance do we think we will transcend our behavior to care about others? That is why with Congressman Gephardt's help we have established a bipartisan task force on the family. We have established the principle that we are going to set schedules we stick to so families can count on time to be together, built around school schedules so that families can get to know each other, and not just by seeing us on C-SPAN.

I will also say that means one of the strongest recommendations of the bipartisan committee, is that we have 17 minutes to vote. This is the bipartisan committee's recommendations, not just mine. They pointed out that if we take the time we spent in the last Congress where we waited for one more Member, and one more, and one more, that we literally can shorten the business and get people home if we will be strict and firm. At one point this year we had a 45-minute vote. I hope all of my colleagues are paying attention because we are in fact going to work very hard to have 17 minute votes and it is over. So, leave on the first bell, not the second bell. Okay? This may seem particularly inappropriate to say on the first day because this will be the busiest day on opening day in congressional history.

I want to read just a part of the Contract With America. I don't mean this as a partisan act, but rather to remind all of us what we are about to go through and why. Those of us who ended up in the majority stood on these steps and signed a contract, and here is part of what it says:

On the first day of the 104th Congress the new Republican majority will immediately pass the following reforms aimed at restoring the faith and trust of the American people in their government: First, require all laws that apply to the rest of the country also to apply equally to the Congress. Second, select a major, independent auditing firm to conduct a comprehensive audit of the Congress for waste, fraud or abuse. Third, cut the number of House committees and cut committee staffs by a third. Fourth, limit the terms of all committee chairs. Fifth, ban the casting of proxy votes in committees. Sixth, require committee meetings to be open to the public. Seven, require a three-fifths majority vote to pass a tax increase. Eight, guarantee an honest accounting of our federal budget by implementing zero baseline budgeting.

Now, I told Dick Gephardt last night that if I had to do it over again we would have pledged within 3 days that we will do these things, but that is not what we said. So we have ourselves in a little bit of a box here.

Then we go a step further. I carry the T.V. Guide version of the contract with me at all times.

We then say that within the first 100 days of the 104 th Congress we shall bring to the House floor the following bills, each to be given full and open debate, each to be given a full and clear vote, and each to be immediately available for inspection. We made it available that day. We listed 10 items. A balanced budget amendment and line-item veto, a bill to stop violent criminals, emphasizing among other things an effective and enforceable death penalty. Third was welfare reform. Fourth, legislation protecting our kids. Fifth was to provide tax cuts for families. Sixth was a bill to strengthen our national defense. Seventh was a bill to raise the senior citizens' earning limit. Eighth was legislation rolling back Government regulations. Ninth was a commonsense legal reform bill, and tenth was congressional term limits legislation.

Our commitment on our side, and this is an absolute obligation, is first of all to work 
today until we are done. I know that is going to inconvenience people who have families and supporters. But we were hired to do a job, and we have to start today to prove we will do it. Second, I would say to our friends in the Democratic Party that we are going to work with you, and we are really laying out a schedule working with the minority leader to make sure that we can set dates certain to go home. That does mean that if 2 or 3 weeks out we are running short we will, frankly, have longer sessions on Tuesday, Wednesday, and Thursday. We will try to work this out on a bipartisan basis to, in a workmanlike way, get it done. It is going to mean the busiest early months since 1933 .

Beyond the Contract I think there are two giant challenges. I know I am a partisan figure. But I really hope today that I can speak for a minute to my friends in the Democratic Party as well as my own colleagues, and speak to the country about these two challenges so that I hope we can have a real dialog. One challenge is to achieve a balanced budget by 2002. I think both Democratic and Republican Governors will say we can do that but it is hard. I do not think we can do it in a year or two. I do not think we ought to lie to the American people. This is a huge, complicated job.

The second challenge is to find a way to truly replace the current welfare state with an opportunity society.

Let me talk very briefly about both challenges. First, on the balanced budget I think we can get it done. I think the baby boomers are now old enough that we can have an honest dialog about priorities, about resources, about what works, and what does not work. Let me say I have already told Vice President Gore that we are going to invite him to address a Republican 215 conference. We would have invited him in December but he had to go to Moscow, I believe there are grounds for us to talk together and to work together, to have hearings together, and to have task forces together. If we set priorities, if we apply the principles of Edwards, Deming and of Peter Drucker we can build on the Vice President's reinventing government effort and we can focus on transforming, not just cutting. The choice becomes not just do you want more or do you want less, but are there ways to do it better? Can we learn from the private sector, can we learn from Ford, IBM, from Microsoft, from what General Motors has had to go through? I think on a bipartisan basis we owe it to our children and grandchildren to get this Government in order and to be able to actually pay our way. I think 2002 is a reasonable time frame. I would hope that together we could open a dialog with the American people.

I have said that I think Social Security ought to be off limits, at least for the first 4 to 6 years of the process, because I think it will just destroy us if we try to bring it into the game. But let me say about everything else, whether it is Medicare, or it is agricultural subsidies, or it is defense or anything that I think the greatest Democratic President of the 20th century, and in my judgment the greatest President of the 20th century, said it right. On March 4, 1933, he stood in braces as a man who had polio at a time when nobody who had that kind of disability could be anything in public life. He was President of the United States, and he stood in front of this Capitol on a rainy March day and he said, 'We have nothing to fear but fear itself.' I want every one of us to reach out in that spirit and pledge to live up to that spirit, and I think frankly on a bipartisan basis. I would say to Members of the Black and Hispanic Caucuses that I would hope 235 we could arrange by late spring to genuinely share districts. You could have a Republican who frankly may not know a thing about your district agree to come for a long weekend with you, and you will agree to go for a long weekend with them. We begin a dialog and an openness that is totally different than people are used to seeing in politics in America. I believe if we do that we can then create a dialog that can lead to a balanced budget.

But I think we have a greater challenge. I do want to pick up directly on what Dick Gephardt said, because he said it right. No Republican here should kid themselves about it. The greatest leaders in fighting for an integrated America in the 20th century were in the Democratic Party. The fact is, it was the liberal wing of the Democratic Party that ended segregation. The fact is that it was Franklin Delano Roosevelt who gave hope to a Nation that was in distress and could have slid into dictatorship. Every Republican has much to learn from studying what the Democrats did right.

But I would say to my friends in the Democratic Party that there is much to what Ronald Reagan was trying to get done. There's much to what is being done today by Republicans like 
Bill Weld, and John Engler, and Tommy Thompson, and George Allen, and Christy Whitman, and Pete Wilson. There is much we can share with each other.

We must replace the welfare state with an opportunity society. The balanced budget is the right thing to do. But it does not in my mind have the moral urgency of coming to grips with what is happening to the poorest Americans.

I commend to all Marvin Olasky's 'The Tragedy of American Compassion.' Olasky goes back for 300 years and looked at what has worked in America, how we have helped people rise beyond poverty, and how we have reached out to save people. He may not have the answers, but he has the right sense of where we have to go as Americans.

I do not believe that there is a single American who can see a news report of a 4-year-old thrown off of a public housing project in Chicago by other children and killed and not feel that a part of your heart went, too. I think of my nephew in the back, Kevin, and how all of us feel about our children. How can any American read about an 11-year-old buried with his Teddy bear because he killed a 14-year-old, and then another 14-year-old killed him, and not have some sense of 'My God, where has this country gone?' How can we not decide that this is a moral crisis equal to segregation, equal to slavery? How can we not insist that every day we take steps to do something?

I have seldom been more shaken than I was after the election when I had breakfast with two members of the Black Caucus. One of them said to me, 'Can you imagine what it is like to visit a first-grade class and realize that every fourth or fifth young boy in that class may be dead or in jail within 15 years? And they are your constituents and you are helpless to change it?' For some reason, I do not know why, maybe because I visit a lot of schools, that got through. I mean, that personalized it. That made it real, not just statistics, but real people.

Then I tried to explain part of my thoughts by talking about the need for alternatives to the bureaucracy, and we got into what I think frankly has been a pretty distorted and cheap debate over orphanages.

Let me say, first of all, my father, who is here today, was a foster child. He was adopted as a teenager. I am adopted. We have relatives who were adopted. We are not talking out of some vague impersonal Dickens 'Bleak House' middle-class intellectual model. We have lived the alternatives.

I believe when we are told that children are so lost in the city bureaucracies that there are children who end up in dumpsters, when we are told that there are children doomed to go to schools where 70 or 80 percent of them will not graduate, when we are told of public housing projects that are so dangerous that if any private sector ran them they would be put in jail, and the only solution we are given is, 'Well, we will study it, we will get around to it,' my only point is that this is unacceptable. We can find ways immediately to do things better, to reach out, break through the bureaucracy and give every young American child a better chance.

Let me suggest to you Morris Schectman's new book. I do not agree with all of it, but it is fascinating. It is entitled 'Working Without a Net.' It is an effort to argue that in the $21 \mathrm{st}$ century we have to create our own safety nets. He draws a distinction between caring and caretaking. It is worth every American reading.

He said caretaking is when you bother me a little bit, and I do enough, I feel better because I think I took care of you. That is not any good to you at all. You may be in fact an alcoholic and I just gave you the money to buy the bottle that kills you, but I feel better and go home. He said caring is actually stopping and dealing with the human being, trying to understand enough about them to genuinely make sure you improve their life, even if you have to start with a conversation like, 'If you will quit drinking, I will help you get a job.' This is a lot harder conversation than, 'I feel better. I gave him a buck or 5 bucks.'

I want to commend every Member on both sides to look carefully. I say to those Republicans who believe in total privatization, you cannot believe in the Good Samaritan and explain that as long as business is making money we can walk by a fellow American who is hurt and not do something. I would say to my friends on the left who believe there has never been a government program that was not worth keeping, you cannot look at some of the results we now have and not want to reach out to the humans and forget the bureaucracies.

If we could build that attitude on both sides of this aisle, we would be an amazingly 
different place, and the country would begin to be a different place.

We have to create a partnership. We have to reach out to the American people. We are going to do a lot of important things. Thanks to the House Information System and Congressman Vern Ehlers, as of today we are going to be on line for the whole country, every amendment, every conference report. We are working with C-SPAN and others, and Congressman Gephardt has agreed to help on a bipartisan basis to make the building more open to television, more accessible to the American people. We have talk radio hosts here today for the first time. I hope to have a bipartisan effort to make the place accessible for all talk radio hosts of all backgrounds, no matter their ideology. The House Historian's office is going to be more aggressively run on a bipartisan basis to reach out to Close Up, and to other groups to teach what the legislative struggle is about. I think over time we can and will this Spring rethink campaign reform and lobbying reform and review all ethics, including the gift rule.

But that isn't enough. Our challenge shouldn't be just to balance the budget or to pass the Contract. Our challenge should not be anything that is just legislative. We are supposed to, each one of us, be leaders. I think our challenge has to be to set as our goal, and maybe we are not going to get there in 2 years. This ought to be the goal that we go home and we tell people we believe in: that there will be a Monday morning when for the entire weekend not a single child was killed anywhere in America; that there will be a Monday morning when every child in the country went to a school that they and their parents thought prepared them as citizens and prepared them to compete in the world market; that there will be a Monday morning where it was easy to find a job or create a job, and your own Government did not punish you if you tried.

We should not be happy just with the language of politicians and the language of legislation. We should insist that our success for America is felt in the neighborhoods, in the communities, is felt by real people living real lives who can say, 'Yes, we are safer, we are healthier, we are better educated, America succeeds.'

This morning's closing hymn at the prayer service was the Battle Hymn of the Republic. It is hard to be in this building, look down past Grant to the Lincoln Memorial and not realize how painful and how difficult that battle hymn is. The key phrase is, 'As he died to make men holy, let us live to make men free.'

It is not just political freedom, although I agree with everything Congressman Gephardt said earlier. If you cannot afford to leave the public housing project, you are not free. If you do not know how to find a job and do not know how to create a job, you are not free. If you cannot find a place that will educate you, you are not free. If you are afraid to walk to the store because you could get killed, you are not free.

So as all of us over the coming months sing that song, 'As he died to make men holy, let us live to make men free,' I want us to dedicate ourselves to reach out in a genuinely nonpartisan way to be honest with each other. I promise each of you that without regard to party my door is going to be open. I will listen to each of you. I will try to work with each of you. I will put in long hours, and I will guarantee that I will listen to you first. I will let you get it all out before I give you my version, because you have been patient with me today, and you have given me a chance to set the stage.

But I want to close by reminding all of us of how much bigger this is than us. Because beyond talking with the American people, beyond working together, I think we can only be successful if we start with our limits. I was very struck this morning with something Bill Emerson used, a very famous quote of Benjamin Franklin, at the point where the Constitutional Convention was deadlocked. People were tired, and there was a real possibility that the Convention was going to break up. Franklin, who was quite old and had been relatively quiet for the entire Convention, suddenly stood up and was angry, and he said:

I have lived, sir, a long time, and the longer I live the more convincing proofs I see of this truth, that God governs in the affairs of men, and if a sparrow cannot fall to the ground without His notice, is it possible that an empire can rise without His aid? At that point the Constitutional Convention stopped. They took a day off for fasting and prayer.

Then, having stopped and come together, they went back, and they solved the great question of large and small States. They wrote the Constitution, and the United States was created. All I can do is pledge to you that, if each of us will reach out prayerfully and try to 
genuinely understand each other, if we will recognize that in this building we symbolize America, and that we have an obligation to talk with each other, then I think a year from now we can look on the 104th Congress as a truly amazing institution without regard to party, without regard to ideology. We can say, 'Here America comes to work, and here we are preparing for those children a better future.' Thank you. Good luck and God bless you. 